\title{
Peningkatan prestasi belajar dengan metode Problem Posing dan bantuan LKS bagi siswa kelas III SDN 03 Talun
}

\author{
Amat Turip \\ SDN 03 Talun, Pekalongan, Kabupaten Pekalongan
}

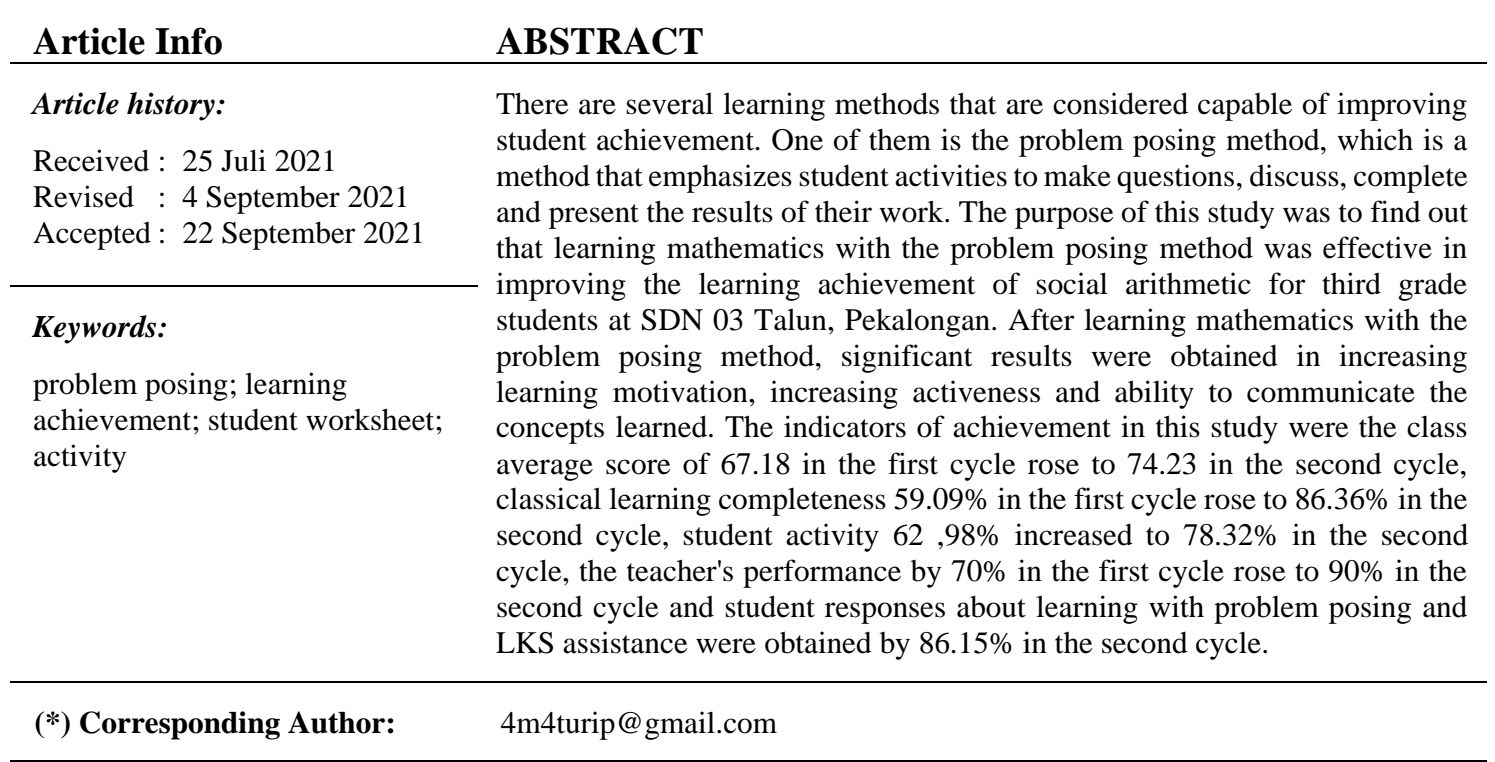

How to Cite: Turip, A. (2021). Peningkatan prestasi belajar dengan metode Problem Posing dan bantuan LKS bagi siswa kelas III SDN 03 Talun. Action Research Journal, 1(1): 6-12.

\section{PENDAHULUAN}

Kemampuan dasar ilmiah dan sikap positif itu dapat dikembangkan bila ditempuh melalui proses pendidikan yang baik. Proses belajar mengajar harus dirancang sedemikian rupa oleh guru sehingga siswa dapat terlibat secara aktif baik fisik maupun mentalnya. Indikator yang dapat dijadikan tolak ukur untuk menyatakan bahwa suatu proses pembelajar dapat dinyatakan berhasil adalah daya serap terhadap bahan dan perilaku siswa (Wulandari \& Susanta, 2018). Pencapaian hasil pembelajaran dipengaruhi oleh berbagai faktor baik yang berasal dari dalam diri siswa maupun dari luar siswa. Salah satu faktor tersebut adalah minat dan sikap seorang siswa dalam belajar. Banyak kasus yang menunjukkan bahwa kesulitan siswa dalam proses pembelajaran tidak hanya disebabkan oleh tingkat kognitif yang rendah saja, tetapi juga disebabkan oleh rendahnya sikap dan minat siswa. Hal ini juga bisa diakibatkan oleh guru, sekolah dan masyarakat yang belum mampu memberikan iklim yang kondusif untuk menumbuhkan minat dan sikap yang baik pada siswa (Saptono, Wahyudi, \& Indarini, 2018).

Kondisi belajar matematika di Kelas III SDN 03 Talun, Pekalongan masih perlu perbaikan. Hal ini dibuktikan dari hasil angket dari kelas III menyatakan 10 anak merasa takut dengan matematika, 6 anak menganggap biasa saja dan hanya 6 anak yang senang dengan matematika. Ini terbukti pada rendahnya minat dan perhatian siswa selama pembelajaran berlangsung. Kebanyakan siswanya pasif, tidak mau bertanya dan belum bisa bekerja sama dalam kelompok. Akibat dari keadaan ini adalah rendahnya nilai matematika siswa, sebanyak 10 siswa yang tuntas dan 12 siswa belum tuntas.

Kenyataan di atas merupakan kendala yang sangat serius untuk mencapai tujuan pembelajaran matematika, untuk itu perlu segera dicari jalan keluarnya. Setiap metode pengajaran mempunyai kelebihan dan kekurangan. Metode problem posing merupakan salah satu alternatif 
yang dapat dilaksanakan dalam pembelajaran matematika. Dalam metode ini siswa diarahkan untuk berpartisipasi aktif dalam pembelajaran (Daniati et al., 2016; Wulandari, H., \& Susanta, 2018). Kelebihan metode problem posing adalah siswa dapat memperoleh pengalaman langsung untuk membuat soal dan menyelesaikannya (Sardin, 2019). Problem posing sebagai pembentukan soal. Pembentukan soal adalah perumusan soal atau mengerjakan soal dari situasi yang tersedia, baik dilakukan sebelum, ketika atau setelah pemecahan masalah (Iqram, 2014; Martiani \& Rachmiati, 2016). Pembentukan soal tersebut mencakup dua kegiatan yaitu pembentukan soal baru dari situasi atau dari pengalaman, dan pembentukan soal lain yang sudah ada.

Menurut National Council for Teacher of Mathematic (NCTM) seperti yang dikutif As'ari (2000) menyatakan bahwa problem posing merupakan the heart of doing mathematic, inti dari bermatematika. Sehingga NCTM merekomendasikan agar para siswa diberi kesempatan yang sebesar-besarnya untuk mengalami membuat soal sendiri (problem posing). Dalam pembelajaran matematika pendekatan problem posing dapat dilakukan secara individu, berpasangan maupun berkelompok (Puspita, Tampubolon, \& Sabri, 2013; Fahmi \& Priwantoro, 2016). Masalah matematika yang diajukan secara individu tidak memuat pemikiran siswa lain. Sedangkan masalah yang diajukan oleh siswa secara berpasangan dapat lebih berbobot. Sama halnya dengan masalah yang dirumuskan dalam kelompok kecil akan menjadi lebih berkualitas manakala anggota kelompok dapat berpartisipasi dengan baik (Darmawati, Kusmariyatni, \& Suarjana , 2014; Hamzah, 2003).

Lembar Kerja Siswa (LKS) bermanfaat menuntun dan melatih siswa untuk bisa menyelesaikan soal dengan langkah yang runtut sehingga diharapkan siswa benar dapat memahami materi dengan baik. Secara umum LKS merupakan perangkat pembelajaran sebagai pelengkap/sarana pendukung Rencana Pelaksanaan Pembelajaran (RPP). LKS sangat baik digunakan untuk menggalakkan keterlibatan siswa dalam belajar baik dipergunakan dalam penerapan metode terbimbing maupun untuk memberikan latihan pengembangan. Berdasarkan latar belakang masalah yang telah dipaparkan di atas, maka permasalahan dalam penelitian tindakan kelas ini dapat dirumuskan sebagai berikut: Apakah dengan penerapan problem posing dan bantuan LKS dapat meningkatkan prestasi belajar siswa kelas III SDN 03 Talun?.

\section{METODE}

Penelitian ini termasuk penelitian tindakan kelas. Subjek dalam penelitian ini adalah kelas 3 SDN 03 Talun Kabupaten Pekalongan. Faktor penting dalam penelitian untuk menjawab permasalahan penelitian adalah: aktivitas dan prestasi belajar siswa dengan menggunakan metode problem posing dan bantuan LKS bagi siswa, dan cara guru merencanakan pembelajaran serta pelaksanaan di dalam kelas setelah menerapkan pembelajaran dengan menggunakan metode problem posing. Penelitian tindakan kelas adalah suatu penelitian yang dilakukan secara sistematis reflektif terhadap berbagai tindakan yang dilakukan oleh guru, mulai dari perencanaan sampai dengan penilaian terhadap tindakan nyata di kelas yang berupa kegiatan belajar mengajar untuk memperbaiki kondisi pembelajaran yang dilakukan. Pada penelitian tindakan kelas ini menggunakan 2 siklus, seperti yang dikemukakan oleh Kemmis \& Robbin Mc Taggart, yaitu: perencanaan, tindakan, pengamatan dan refleksi.

Teknik dan alat pengumpulan data daalam penelitian tindakan kelas ini meliputi: observasi, angket dan tes. Observasi yang digunakan adalah pengamat tidak sepenuhnya sebagai pemeran serta tetapi masih melakukan fungsi pengamat menjadi anggota kelompok yang diamati. Observasi dilakukan untuk memperoleh informasi mengenai tingkat minat siswa dalam kelompok selama mengikuti kegiatan pembelajaran. Angket merupakan proses memperoleh keterangan untuk tujuan penelitian dengan cara memberikan daftar pertanyaan yang telah dipersiapkan, untuk memperoleh informasi sejauh mana penerapan metode problem posing memberi kesan siswa selama mengikuti pelajaran. Tes adalah proses untuk memperoleh informasi dengan cara memberikan soal tes yang harus dikerjakan oleh siswa, yang dapat digunakan untuk mengetahui tingkat penguasaan materi pelajaran yang telah diberikan dan hasil belajar siswa. 
Dalam penelitian tindakan kelas ini, sebagai tolak ukur keberhasilan penelitian dapat dilihat dari: '1) meningkatnya keaktifan siswa dalam proses pembelajaran matematika dengan kategori tinggi, 2) meningkatnya hasil belajar siswa yang ditunjukkan dengan kemampuan siswa dalam menyelesaikan soal. Indikator keberhasilannya adalah apabila siswa yang memperoleh nilai $\geq 70$ mencapai $85 \%$ dan rata-rata kelas mencapai 70 , dan 3) meningkatnya kemampuan guru dalam melaksanakan problem posing mencapai $85 \%$ dengan kategori tinggi.

\section{HASIL DAN PEMBAHASAN}

\section{Hasil}

Siklus 1

1. Perencanaan

a. Guru perangkat pembelajaran meliputi: silabus, rencana persiapan pembelajaran, lembar kerja siswa dan soal tes.

b. Guru membuat lembar observasi untuk guru dan untuk siswa pada pelaksanaan proses belajar mengajar di kelas.

c. Guru menyiapkan kuisioner tanggapan siswa dalam tentang proses pembelajaran dengan menggunakan metode problem posing.

\section{Tindakan}

Tindakan yang dilakukan dalam siklus 1 adalah sebagai berikut:

a. Guru menyajikan materi ajar sesuai dengan rencana pelaksanaan pembelajaran

b. Guru mengelompokkan siswa menjadi beberapa kelompok

c. Guru menyuruh siswa membuat soal dan penyelesaiannya kemudian soal tadi ditukarkan dengan teman satu kelompok untuk dikerjakan.

d. Siswa melaporkan tugas dan mempresentasikan pekerjaan di depan kelas.

e. Siswa mengerjakan LKS dengan bimbingan guru dan diberi tugas rumah.

f. Pada akhir pertemuan guru memberikan post tes.

3. Pengamatan.

Pengamatan terhadap siswa dilakukan selama proses pembelajaran berlangsung dilakukan pengamatan terhadap siswa yaitu: kemampuan siswa memahami konsep, kemampuan siswa berdiskusi dengan teman, kemampuan siswa untuk bertanya, kemampuan siswa menjawab pertanyaan, dan motivasi siswa. Dari pengamatan diperoleh dari aktivitas siswa dalam bertanya, menjawab pertanyaan dari temen maupun dari guru dan mengemukakan pendapat. Data keaktifan siswa ini memperoleh persentase 62,98\%, dengan kategori sedang. Data pengamatan terhadap guru berdasarkan atas: merencanakan proses pembelajaran, penguasaan bahan ajar, penguasaan kelas, membangkitkan motivasi belajar siswa, memberi kesempatan siswa untuk bertanya, memberi pertanyaan lisan pada siswa saat pembelajaran, memberi penguatan atas jawaban siswa, dan memberikan tugas untuk siswa. Dalam melakukan pembelajaran di siklus I persentase yang diperoleh guru adalah $70 \%$. Secara keseluruhan bahwa guru dalam melaksanakan pengajaran baik. Dari hasil ulangan harian pada siklus 1 diperoleh data bahwa besarnya nilai rata-rata 67,18, dengan ketuntasan klasikal mencapai $59,09 \%$. Siswa yang belum mencapai nilai ketuntasan masih cukup banyak yaitu sedangkan yang sudah tuntas ada 12 siswa dari kriteria ketuntasan minimal. Hasil ini masih belum seperti yang diharapkan sehingga proses pembelajaran masih harus dioptimalkan.

4. Refleksi

Setelah proses pembelajaran siklus 1, peneliti bersama dengan guru mendiskusikan hasil pengamatan yang selanjutnya digunakan untuk perbaikan pada siklus 2. Dari hasil kegiatan pada siklus 1 masih belum mencapai harapan maka perlu dilakukan perbaikan - perbaikan pada siklus 2, yaitu :

a. Memberi pengertian kepada siswa agar tidak merasa diawasi oleh kehadiran guru pengamat. 
b. Perlu memberi motivasi kepada siswa untuk aktif dalam diskusi, lebih berani untuk bertanya, lebih berani mengemukakan pendapat, jangan takut salah atau ditertawakan teman.

c. Pengelolaan waktu dalam proses pembelajaran perlu diperhatikan shingga sesuai dengan desain pembelajaran.

Beberapa catatan juga ditemukan oleh guru pengamat antara lain:

a. Persiapan awal sebelum dimulai proses pembelajaran memakan waktu sehingga pemanfaatan waktu belum optimal.

b. Dalam proses pembelajaran peran guru masih dominan.

c. Sebagian siswa masih canggung dalam mengikuti proses pembelajaran. Hal itu dimungkinkan karena pengaruh psikologis akibat kehadiran guru pengamat yang ikut mengobservasi aktivitas siswa dan aktivitas guru peneliti, sehingga siswa merasa diamati.

Siklus 2

1. Perencanaan

a. Guru perangkat pembelajaran meliputi: silabus, rencana persiapan pembelajaran, lembar kerja siswa dan soal tes.

b. Guru membuat lembar observasi untuk guru dan untuk siswa pada pelaksanaan proses belajar mengajar di kelas.

c. Guru menyiapkan kuisioner tanggapan siswa dalam tentang proses pembelajaran dengan menggunakan metode problem posing.

2. Tindakan

Tindakan yang dilakukan dalam siklus 2 adalah sebagai berikut:

a. Guru menyajikan materi ajar sesuai dengan rencana pelaksanaan pembelajaran

b. Guru mengelompokkan siswa menjadi beberapa kelompok

c. Guru menyuruh siswa membuat soal dan penyelesaiannya kemudian soal tadi ditukarkan dengan teman satu kelompok untuk dikerjakan.

d. Siswa melaporkan tugas dan mempresentasikan pekerjaan di depan kelas.

e. Siswa mengerjakan LKS dengan bimbingan guru dan diberi tugas rumah.

f. Pada akhir pertemuan guru memberikan post tes.

3. Pengamatan.

Pengamatan terhadap siswa dilakukan selama proses pembelajaran berlangsung dilakukan pengamatan terhadap siswa yaitu: kemampuan siswa memahami konsep, kemampuan siswa berdiskusi dengan teman, kemampuan siswa untuk bertanya, kemampuan siswa menjawab pertanyaan, dan motivasi siswa. Dari pengamatan diperoleh dari aktivitas siswa dalam bertanya, menjawab pertanyaan dari temen maupun dari guru dan mengemukakan pendapat. Data keaktifan siswa ini memperoleh persentase $78,32 \%$, dengan kategori tinggi. Data pengamatan terhadap guru berdasarkan atas: merencanakan proses pembelajaran, penguasaan bahan ajar, penguasaan kelas, membangkitkan motivasi belajar siswa, memberi kesempatan siswa untuk bertanya, memberi pertanyaan lisan pada siswa saat pembelajaran, memberi penguatan atas jawaban siswa, dan memberikan tugas untuk siswa. Dalam melakukan pembelajaran di siklus II persentase yang diperoleh guru adalah 90\%. Secara keseluruhan bahwa guru dalam melaksanakan pengajaran baik. Dari hasil ulangan harian pada siklus II diperoleh data bahwa besarnya nilai rata-rata 74,23, dengan ketuntasan klasikal mencapai $86,15 \%$. Siswa yang belum mencapai nilai ketuntasan masih cukup banyak yaitu sedangkan yang sudah tuntas ada 19 siswa dari kriteria ketuntasan minimal.

4. Refleksi

Setelah proses pembelajaran siklus 2, peneliti dan guru mendiskusikan hasil pengamatan penyajian siklus 2. Dari hasil angket kesan siswa dan penilaian hasil ulangan harian dapat disimpulkan bahwa pelaksanaan pembelajaran pada siklus II ini lebih optimal dibanding pelaksanaan siklus I. Beberapa catatan ditemukan oleh guru pengamat yaitu: pemanfanfatan waktu lebih opfimal dibanding siklus I, dalam kerja kelompok siswa berjalan lebih optomal, 
siswa tidak canggung lagi dengan adanya guru pengamat, dan hasil belajar siswa lebih meningkat.

\section{Pembahasan}

Jelas disajikan pada Tabel 1 bahwa indikator ketercapaian dalam penelitian ini adalah nilai rata-rata kelas sebesar 67,18 pada siklus I naik menjadi 74,23 pada siklus II, ketuntasan belajar klasikal 59,09\% pada siklus I naik menjadi 86,36\% pada siklus II, keaktifan siswa $62,98 \%$ naik menjadi 78,32\% pada siklus 2, kinerja guru sebesar 70\% pada siklus I naik menjadi $90 \%$ pada siklus II dan tanggapan siswa tentang pembelajaran dengan problem posing dan bantuan LKS diperoleh sebesar $86,15 \%$ pada siklus II.

Tabel 1. Data Pra Siklus, Siklus I, dan Siklus II

\begin{tabular}{lccc}
\hline & Pra Siklus & Siklus I & Siklus II \\
\hline Rata-rata prestasi belajar & 60 & 67,18 & 74,23 \\
Persentase siswa tuntas belajar (\%) & 50 & 59,09 & 86,36 \\
Persentase siswa tidak tuntas belajar (\%) & 50 & 40,91 & 13,64 \\
Keaktifan siswa & 60 & 67,23 & 74,23 \\
Kinerja guru dalam pembelajaran & 65 & 70 & 90 \\
\hline
\end{tabular}

Gambar 1 juga menunjukkan bahwa peningkatan aktifitas siswa juga diikuti oleh peningkatan keaktifan guru dalam mengelola pembelajaran. Kekurangan, hambatan dan kendala memang harus segera ditindaktanjuti, maka guru harus memperbaiki kemampuan dalam pengelolaan kelas. Kekurangan dan kesalahan yang terjadi pada pembelajaran sebelumnya harus diperbaiki pada pembelajaran selanjutnya. Melalui pembelajaran problem posing dan bantuan $L K S$, siswa dapat mengaitkan pengetahuan yang telah dipelajarinya dengan kejadian dalam kehidupan sehari-hari (Iqram, 2014; Sardin, 2019; Darmawati, Kusmariyatni, \& Suarjana, 2014). Dalam membuat soal dan penyelesaiannya siswa diberi kesempatan untuk menyampaikan ideidenya, sehingga banyak siswa yang berani membuat penyelesaian yang berbeda dengan temantemannya, yang sebelumnya mereka sudah membuat soal menyelesaikan secara berkelompok (Puspita, Tampubolon, \& Sabri, 2013; Fahmi \& Priwantoro, 2016). Dengan menerapkan model pembelajaran problem posing dan bantuan $L K S$ siswa bisa saling bertukar pendapat dengan teman sekelompok maupun kelompok lain dengan tetap saling menghargai pendapat orang lain.

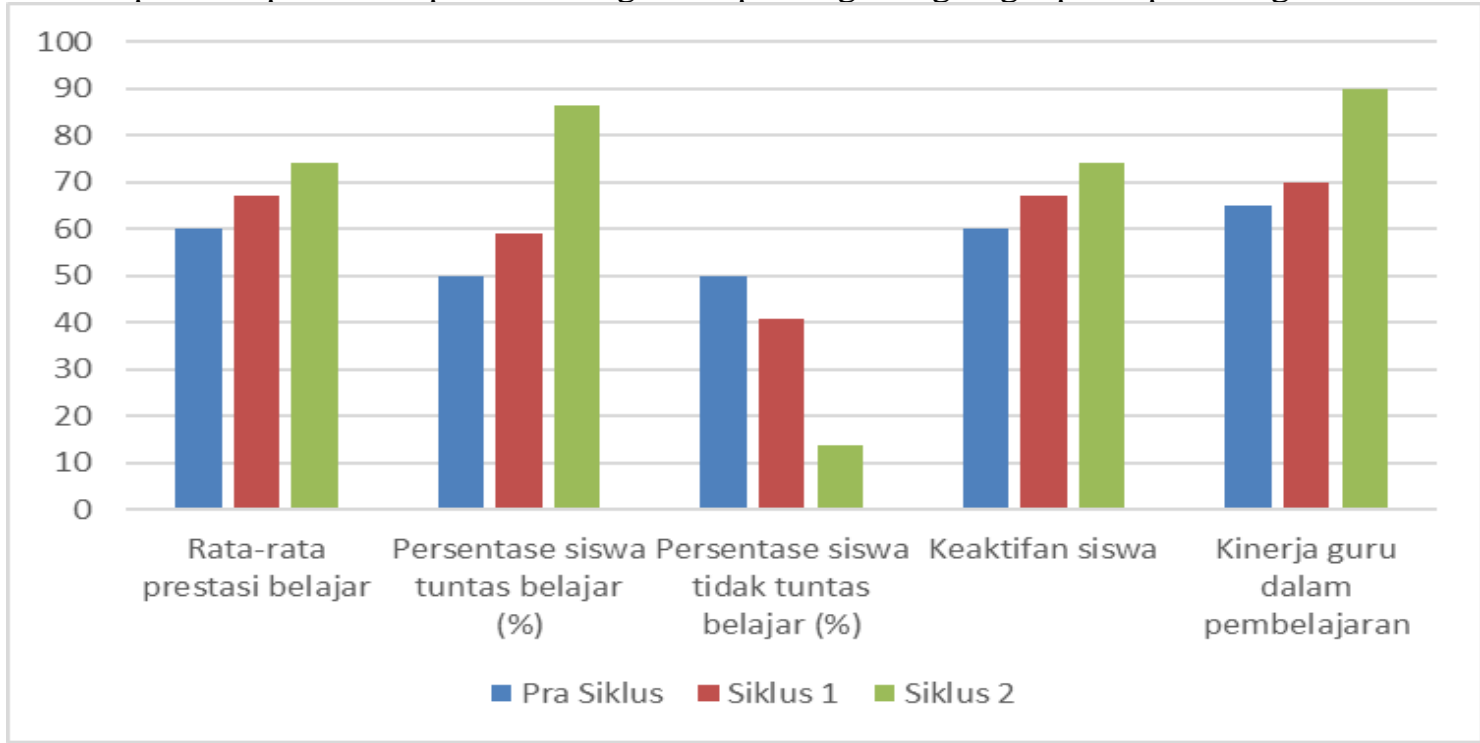

Gambar 1. Perbandingan Data Penelitian

Penerapan model pembelajaran problem posing dan bantuan LKS ini perlu terus dioptimalkan untuk meningkatkan prestasi siswa. Penerapan model pembelajaran problem posing dan bantuan LKS juga dapat digunakan untuk meningkatkan keterampilan komunikasi siswa, karena dalam pembelajarannya ada presentasi di depan kelas untuk menjelaskan hasil kerjanya kepada siswa lain kemudian siswa yang lain dapat menyanggahnya dan disinilah terjadi kegiatan 
saling menyampaikan pendapat. Sehingga siswa yang kurang mampu untuk menyampaikan pendapat pada orang lain dapat terus dilatih. Pada saat siswa menyampaikan pendapatnya guru juga menghargai keberagaman pendapat yang dimiliki para siswa. Pengenalan pembelajaran problem posing dan bantuan LKS kepada para siswa juga akan mengenalkan pada siswa bahwa dalam kehidupan sehari-hari mereka nantinya akan menjumpai berbagai masalah yang harus mereka selesaikan (Martiani \& Rachmiati, 2016; Saptono, Wahyudi, \& Indarini, 2018). Hasil penelitian ini relevan dengan pendapat dan hasil penelitian sebelumnya, yaitu Martiani \& Rachmiati (2016) yang menyatakan bahwa metode problem posing dapat meningkatkan pemahaman siswa dan memberikan kebermaknaan dalam belajar. Kebermaknaan ini mengandung maksud bahwa konsep yang diperoleh sebagai hasil belajar dapat ditransformasikan dalam situasi lain dan dapat dijadikan sebagai bekal untuk memecahkan masalah - masalah yang dihadapi siswa pada saat sekarang atau kelak di kemudian hari.

\section{PENUTUP}

Berdasarkan hasil penelitian tindakan kelas yang telah dilaksanakan dapat disimpulkan bahwa model pembelajaran dengan menggunakan metode problem posing dan bantuan LKS dapat meningkatkan prestasi belajar, keaktifan dan kinerja guru dalam pembelajaran. Indikator ketercapaian dalam penelitian ini adalah nilai rata-rata kelas sebesar 67,18 pada siklus I naik menjadi 74,23 pada siklus II, ketuntasan belajar klasikal 59,09\% pada siklus I naik menjadi $86,36 \%$ pada siklus II, keaktifan siswa $62,98 \%$ naik menjadi $78,32 \%$ pada siklus 2 , kinerja guru sebesar $70 \%$ pada siklus I naik menjadi $90 \%$ pada siklus II dan tanggapan siswa tentang pembelajaran dengan problem posing dan bantuan LKS diperoleh sebesar 86,15\% pada siklus II. Untuk mencapai hasil pembelajaran yang maksimal guru harus menyiapkan pembelajaran sebaik mungkin dengan mengaktifkan siswa, menyusun LKS dan materi sesuai dengan metode yang digunakan.

\section{DAFTAR PUSTAKA}

As'Ari, A. (2000). Pembelajaran matematika dengan pendekatan problem posing. Jakarta: Pelangi Pendidikan.

Daniati, S. P., Yulianti, H. M., \& Kamsiyati, S. (2016). Peningkatan kemampuan menghitung bilangan bulat melalui model pembelajaran problem posing. Didaktika Dwija Indria, 4(4).

Darmawati, N. K. S., Kusmariyatni, N., \& Suarjana, I. M. (2014). Penerapan metode problem posing untuk meningkatkan aktivitas dan hasil belajar matematika pada siswa kelas IV SD No. 4 Taman Kecamatan Abiansemal Kabupaten Badung. MIMBAR PGSD Undiksha, 2(1).

Fahmi, S., \& Priwantoro, S. W. (2016). Upaya meningkatkan kreatifitas belajar mahasiswa pendidikan matematika menggunakan geogebra dengan pendekatan problem posing. Jurnal Ilmiah Matematika dan Pendidikan Matematika, 8(2), 69-80.

Hamzah. (2003). Problem posing dan problem solving dalam pembelajaran matematika. Bandung: Pustaka Pendidikan.

Iqram, W. (2014). Upaya meningkatkan hasil belajar matematika melalui penerapan model pembelajaran kooperatif problem posing SMP Negeri 2 Baraka, Kabupaten Enrekang. Jurnal Nalar Pendidikan, 2(1).

Martiani, E., \& Rachmiati, W. (2016). Penerapan model problem posing untuk meningkatkan hasil belajar matematika tentang operasi hitung campuran. Ibtida 'i: Jurnal Kependidikan Dasar, 3(2), 157.

Puspita, D. Y. R., Tampubolon, B., \& Sabri, T. (2013). Pelaksanaan pembelajaran matematika menggunakan model problem posing untuk meningkatkan aktivitas dan hasil belajar siswa kelas V. Jurnal Pendidikan dan Pembelajaran Khatulistiwa, 2(6). 
Saptono, B., Wahyudi, W., \& Indarini, E. (2018). Penerapan motode pembelajaran problem posing untuk meningkatkan kemampuan pemecahan masalah pengukuran sudut dengan busur derajat siswa Kelas 4 SDN Barukan 02. Kalam Cendekia PGSD Kebumen, 6(4.1).

Sardin, S. (2019). Meningkatkan kemampuan berpikir kreatif matematika siswa pada pokok bahasan bilangan melalui pendekatan problem posing. Jurnal Theorems, 4(1), 301759.

Wulandari, H., \& Susanta, A. (2018). Penerapan model pembelajaran problem posing tipe post solution posing untuk meningkatkan hasil belajar siswa kelas VIII di SMP Negeri 1 Bengkulu Tengah. Jurnal Penelitian Pembelajaran Matematika Sekolah (JP2MS), 2(1), $1-7$. 